\title{
Surface heat fluxes and subsurface heat content at a site over the southeastern Bering Sea shelf, May-July 1996
}

\author{
R.K. Reed*, P.J. Stabeno \\ NOAA/Pacific Marine Environmental Laboratory, 7600 Sand Point Way NE, Seattle, WA 98115-6349, USA
}

\begin{abstract}
Observations from a surface mooring, in a weak-flow regime over the southeastern Bering Sea shelf, were used to derive surface heat fluxes for the period May-July 1996. Changes in heat content of the water column also were determined from subsurface temperature measurements. Agreement of net surface heat flux and change in heat content was within $2 \%$. This result provides additional evidence that heat advection and diffusion are small in this region. (C) 2002 Elsevier Science Ltd. All rights reserved.
\end{abstract}

\section{Introduction}

The southeastern Bering Sea shelf is a region of very weak baroclinic flow (Fig. 1). This feature was clearly demonstrated by current measurements and hydrographic sections, starting in 1975 , as part of the Outer Continental Shelf Environmental Assessment Program, which was administered by the National Oceanic and Atmospheric Administration for the Bureau of Land Management. Kinder and Schumacher (1981) and Schumacher and Kinder (1983) presented evidence for this weak flow. Later, Coachman (1986) and Stabeno et al. (2001) published comprehensive studies.

Reed (1978) used data over the shelf from midJune to early August 1976 and found that the change in heat content of the water column, during the major period of heating, equaled the surface heat exchange as derived by empirical formulae (discussed below). Of the surface fluxes, $88 \%$ was from insolation. This situation resulted from the

\footnotetext{
*Corresponding author.

E-mail address: reed@pmel.noaa.gov (R.K. Reed).
}

weak winds (a mean of $4 \mathrm{~m} \mathrm{~s}^{-1}$ ), substantial cloud cover (0.93), and small air-sea temperature differences. Estimates also showed that heat advection and diffusion were no more than $\sim 5 \%$ of the surface heat flux.

The present study uses results for May-July 1996, from a site near the region investigated by Reed (1978). The location of the site, mooring 2, is shown in Fig. 1, as well as a schematic of the climatological mean circulation from Reed and Stabeno (1996). All of the atmospheric and oceanic variables needed for a heat budget study were measured, except for cloud cover, which was derived from measured insolation by an empirical formula discussed below.

\section{Data and methods}

\subsection{Instruments and measurements}

A surface mooring (mooring 2; Fig. 1) has been deployed each year, typically from late April to mid-September, from 1995 to the present. Details 


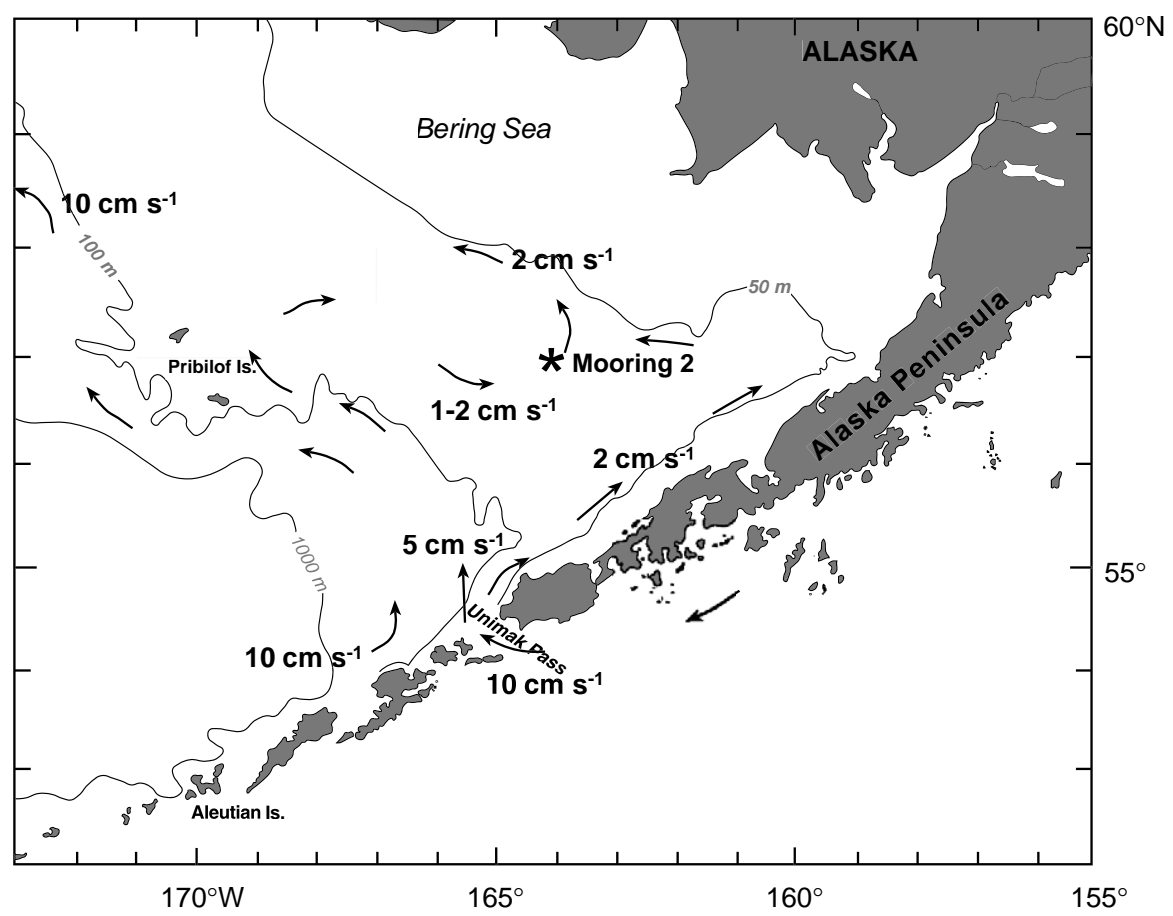

Fig. 1. Location of mooring 2 over the southeastern Bering Sea shelf. A schematic of the climatological sea surface circulation, from Reed and Stabeno (1996), is also shown.

about the mooring are contained in Stabeno et al. (1998). The surface buoy was a $2.3 \mathrm{~m}$ diameter fiberglass toroid, connected by chain to a tether and an anchor at $72 \mathrm{~m}$. The float could move horizontally $\sim 60 \mathrm{~m}$.

The surface float, which extended upward $\sim 3 \mathrm{~m}$, contained an Eppley Precision Spectral Pyranometer that measured solar radiation from $\sim 0.3$ to $2.8 \mu \mathrm{m}$, an R.M. Young model 05103 wind sensor, a Rotronics model MP100 air temperature/relative humidity sensor, and a Yellow Springs Instruments model 44006 thermistor that measured sea-surface temperature. Subsurface temperature was measured, with Seabird Electronics model SBE-16 Seacat temperature/conductivity sensors or Miniature Temperature Recorders constructed in our laboratory, at levels of $6,8,12$, $15,20,24,27,31,34,39,44,50,56$, and $62 \mathrm{~m}$. All sensors were calibrated in our laboratory or by the manufacturer a few months prior to and after use. Temperature accuracy was $\sim 0.02^{\circ} \mathrm{C}$.
The only year with complete data return was 1996. All other years had some incomplete surface observations. We have thus used observations during the period of major heating of the water column (May-July) in 1996.

\subsection{Surface heat fluxes}

Exchange of heat across the sea surface may be written as

$Q_{\mathrm{t}}=Q_{\mathrm{s}}-Q_{\mathrm{b}}-Q_{\mathrm{e}}-Q_{\mathrm{h}}$,

where $Q_{\mathrm{t}}$ is the total or net exchange, $Q_{\mathrm{s}}$ is the solar radiation (insolation), $Q_{\mathrm{b}}$ is the net back or long wave (infrared) radiation, $Q_{\mathrm{e}}$ is the loss of latent heat through evaporation of water, and $Q_{\mathrm{h}}$ is the sensible heat loss.

The term $Q_{\text {s }}$ is much larger than the other surface fluxes. As stated above, insolation was measured with a pyranometer and should be more reliable than the other fluxes, which were derived 
from empirical formulas. Having measured $Q_{\mathrm{s}}$, we derived cloud cover ( $C$, in tenths) from the relation

$Q_{\mathrm{s}} / Q_{\mathrm{o}}=1-0.62 \mathrm{C}+0.0019 \alpha$,

where $Q_{\mathrm{o}}$ is the insolation under clear skies (Seckel and Beaudry, 1973), and $\alpha$ is the noon solar altitude (in degrees). Eq. (2), from Reed (1977), has been used widely (Weare et al., 1981; Josey et al., 1999) and appears to give reasonable results over various regions. Finally, the flux $Q_{\mathrm{s}}$ was reduced by $6 \%$ for reflected short wave radiation (Payne, 1972).

The net long wave radiation, $Q_{\mathrm{b}}$, was derived from Efimova's formula (Budyko, 1974):

$$
\begin{aligned}
& Q_{\mathrm{b}}=\varepsilon \sigma T_{\mathrm{s}}^{4}\left(0.254-0.00495 e_{\mathrm{a}}\right) \\
& \quad(1-0.9 C)+4 \varepsilon \sigma T_{\mathrm{s}}^{3}\left(T_{\mathrm{s}}-T_{\mathrm{a}}\right),
\end{aligned}
$$

where $\varepsilon$ is the emissivity of the sea surface $(0.98), \sigma$ is the Stefan-Boltzman constant $\left(5.7 \times 10^{-8} \mathrm{~W}\right.$ $\left.\mathrm{m}^{-2} \mathrm{~K}^{-4}\right), e_{\mathrm{a}}$ is the air vapor pressure, and $T_{\mathrm{s}}$ and $T_{\mathrm{a}}$ are the absolute sea surface and air temperature, respectively. Moisan and Niiler (1998) used this formula, but with different cloud factors. It should be noted that others (Josey et al., 1999, for example) used the Berliand and Berliand formula (Budyko, 1974) with a nonlinear cloud factor. Our use of (3) is based on: (1) Reed's (1976) summary of measurements that indicated a factor of $1-0.9 \mathrm{C}$ for low stratus-stratocumulus clouds typical of high latitudes; and (2) the plausible results from Eq. (3) for the 1976 Bering Sea heat budget (Reed, 1978).

Finally, latent and sensible heat fluxes were computed from

$Q_{\mathrm{e}}=\rho L U\left(q_{\mathrm{s}}-q_{\mathrm{a}}\right) C_{\mathrm{e}}$

and

$Q_{\mathrm{h}}=\rho c_{p} U\left(T_{\mathrm{s}}-T_{\mathrm{a}}\right) C_{\mathrm{h}}$,

where $\rho$ is the specific air density $\left(1.3 \times 10^{-3}\right), L$ is the latent heat of vaporization $\left(\sim 2.5 \times 10^{6} \mathrm{~W} \mathrm{~s}\right.$ $\left.\mathrm{kg}^{-1}\right), U$ is the wind speed $\left(\mathrm{m} \mathrm{s}^{-1}\right), c_{p}$ is the specific heat capacity of air $\left(\sim 1 \times 10^{6} \mathrm{~W} \mathrm{~s} \mathrm{~m}^{-3} \mathrm{~K}^{-1}\right), q_{\mathrm{s}}$ and $q_{\mathrm{e}}$ are the specific humidity of sea water and air, $T_{\mathrm{s}}$ and $T_{\mathrm{a}}$ are the sea and air temperature, and $C_{\mathrm{e}}$ and $C_{\mathrm{h}}$ are taken as $1.2 \times 10^{-3}$ and $1.0 \times 10^{-3}$, respectively. These values, for the light winds here, are similar to Smith (1988), as well as to earlier results of Friehe and Schmitt (1976) used by Reed (1978).
It should be noted that fluxes computed from monthly means of water and air properties were not significantly different than monthly means of computed daily fluxes.

\subsection{Heat content}

The heat content of the water column was determined from

$H=\rho c_{p} \int T \mathrm{~d} z$,

where $\rho$ is the seawater density, $c_{p}$ is the specific heat of seawater at constant pressure, $T$ is the water temperature, and $z$ is the vertical axis.

\section{Results}

\subsection{Air and water properties}

Fig. 2 presents daily mean observed values of wind speed, air temperature, sea-surface temperature, and insolation at mooring 2 for May-July 1996. Wind speed was $5.3 \pm 1.8 \mathrm{~m} \mathrm{~s}^{-1}$ during May, $6.9 \pm 2.4 \mathrm{~m} \mathrm{~s}^{-1}$ during June, and $5.9 \pm 1.9 \mathrm{~m} \mathrm{~s}^{-1}$ during July. These values are all greater than that $\left(4 \mathrm{~m} \mathrm{~s}^{-1}\right)$ during the June-August 1976 period (Reed, 1978). Fig. 2 indicates a general increasing trend of air temperature with time but with numerous deviations. Air temperatures were $2.8 \pm 1.2,5.1 \pm 1.3$, and $8.7 \pm 1.2^{\circ} \mathrm{C}$ for May, June, and July, respectively. Sea-surface temperatures were $2.3 \pm 1.2,4.9 \pm 0.7$, and $8.3 \pm 1.1^{\circ} \mathrm{C}$ for May, June, and July, respectively. Insolation was greatest in May, even though clear-sky values were greatest in June. The extreme high-frequency variations result mainly from rapid changes in cloud cover. Computed mean cloud cover, from the measured insolation and use of Eq. (2), was $0.79,1.00$, and 1.02 for May, June, and July, respectively. (The cloud cover was not greater than 1.0 , but the atmospheric transmission was probably reduced additionally by fog, drizzle, rain, high humidity, or other factors.) The most unanticipated result is that May had lighter winds, clearer skies, and greater insolation than the "summer" months of June and July. 

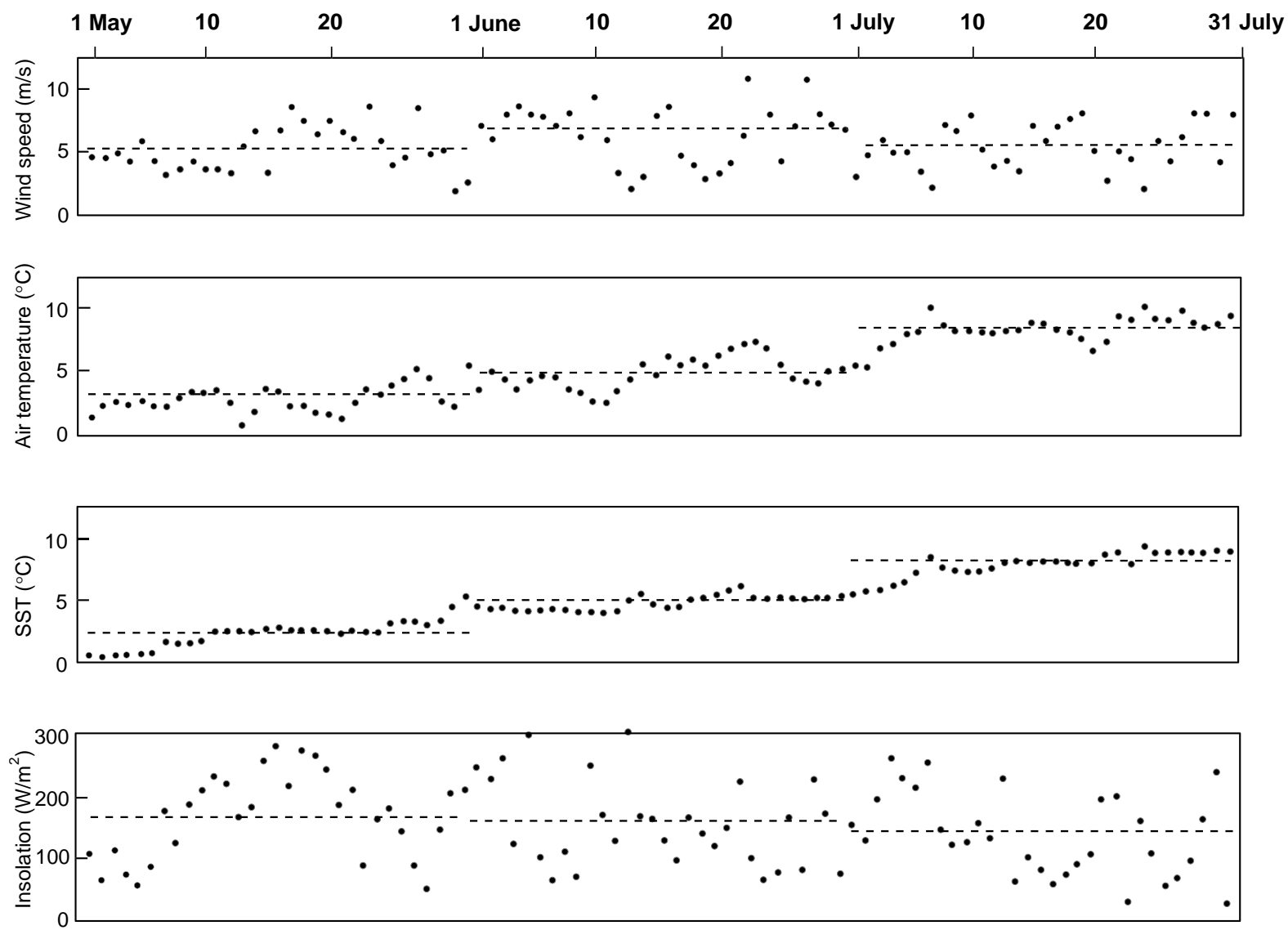

Fig. 2. Daily mean values of measured wind speed $\left(\mathrm{m} \mathrm{s}^{-1}\right)$, air temperature $\left({ }^{\circ} \mathrm{C}\right)$, sea surface temperature $\left({ }^{\circ} \mathrm{C}\right)$, and insolation $\left(\mathrm{W} \mathrm{m}{ }^{-2}\right)$ at mooring 2, May-July 1996. The dashed lines indicate the monthly mean properties.

Considerable variability also exists on daily time scales as well as on the monthly scales given above. The mean diurnal standard deviations in wind speed, air temperature, and sea-surface temperature were $1.3 \mathrm{~m} \mathrm{~s}^{-1}, 0.4^{\circ} \mathrm{C}$, and $0.2^{\circ} \mathrm{C}$, respectively, with no significant difference in these values in May, June, and July 1996. There were, however, nearly ten-fold day-to-day differences in diurnal variability. Finally, these "event-scale" variations of wind-speed, air-temperature, and sea-surface temperature had weak correlations.

Bond and Adams (2002) have examined conditions during 1995-1999 in relation to a 40-year mean reanalysis of water properties and fluxes (Kalnay et al., 1996). Summer 1996 was near the climatological mean in most respects but had stronger than normal wind mixing much of the
Table 1

Summary of observed and computed surface heat fluxes (in $\left.\mathrm{W} \mathrm{m}^{-2}\right)$ at Mooring $2\left(56^{\circ} 52^{\prime} \mathrm{N}, 164^{\circ} 3^{\prime} \mathrm{W}\right)$, May-July 1996

\begin{tabular}{lrrrr}
\hline & May & June & July & Mean \\
\hline $0.94 Q_{\mathrm{s}}$ & 173 & 157 & 148 & 159 \\
$Q_{\mathrm{b}}$ & 18 & 6 & 4 & 9 \\
$Q_{\mathrm{e}}$ & 9 & 16 & 9 & 11 \\
$Q_{\mathrm{h}}$ & -4 & -2 & -3 & -3 \\
$Q_{\mathrm{t}}$ & 150 & 137 & 138 & 142 \\
$\partial H / \partial t$ & 141 & 156 & 137 & 145 \\
\hline
\end{tabular}

The changes in heat content of the water column, $\partial H / \partial t$ $\left(\mathrm{W} \mathrm{m}^{-2}\right)$, are also shown. The standard error of estimate in $\partial H / \partial t$ is $\sim 2 \mathrm{~W} \mathrm{~m}^{-2}$, or $\sim 4 \mathrm{~W} \mathrm{~m}^{-2}$ at $95 \%$ confidence limits.

time and below normal insolation (by $\sim 40 \mathrm{~W} \mathrm{~m}^{-2}$ ) during the second half of June. The long-term mean summer surface heat flux $\left(Q_{\mathrm{t}}\right)$ was $\sim 15 \%$ greater than our value (Table 1). This comparison 


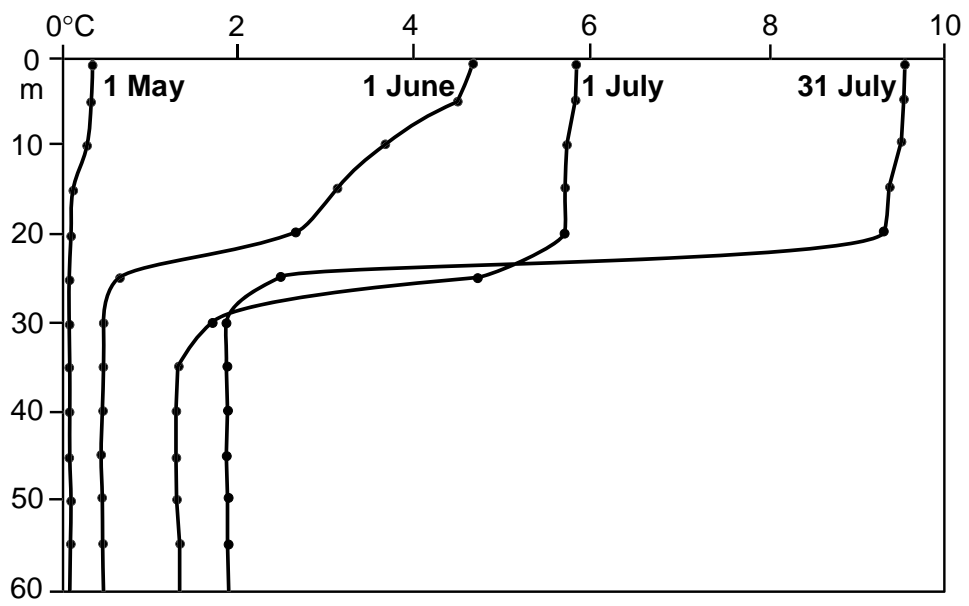

Fig. 3. Subsurface thermal structure $\left({ }^{\circ} \mathrm{C}\right)$ at mooring 2, May-July 1996.

may not be very meaningful, however, because of the different methods used by Kalnay et al. (1996) and us. Results of Hermann et al. (2002) suggest that the reanalysis fluxes may be too high.

Fig. 3 shows the changes in temperature in the water column during May-July 1996. In May, surface temperature increased from $<0.4^{\circ} \mathrm{C}$ to $>4.5^{\circ} \mathrm{C}$; temperature below $30 \mathrm{~m}$ increased by $<0.4^{\circ} \mathrm{C}$, however. In June, surface temperature increased by $\sim 1.1^{\circ} \mathrm{C}$, temperature at $30 \mathrm{~m}$ increased by $\sim 1.3^{\circ} \mathrm{C}$, and bottom temperatures increased by $\sim 0.9^{\circ} \mathrm{C}$. During July, surface temperature increased by almost $4^{\circ} \mathrm{C}$, temperature at $25 \mathrm{~m}$ decreased by $>2^{\circ} \mathrm{C}$, and the water warmed by $\sim 0.6^{\circ} \mathrm{C}$ below $30 \mathrm{~m}$. The total changes from 1 May to 31 July were $\sim 9^{\circ} \mathrm{C}$ at the surface and slightly less than $2^{\circ} \mathrm{C}$ at $30 \mathrm{~m}$ and below.

\subsection{Surface fluxes}

The measured and computed surface heat fluxes are listed in Table 1. The largest total heat flux $\left(Q_{\mathrm{t}}\right.$, $150 \mathrm{~W} \mathrm{~m}^{-2}$ ) occurred in May. This resulted from relatively small cloud cover and light winds. In June and July, $Q_{\mathrm{b}}$ values were smaller than in May because of increased cloud cover then. June had the largest latent heat flux as a result of the strongest winds. For the entire May-July period,
$0.94 Q_{\mathrm{s}}$ is $87 \%$ of the sum of the absolute values of the fluxes.

Use of the Berliand and Berliand formula (Budyko, 1974) for $Q_{\mathrm{b}}$, with a nonlinear cloud factor, as noted above and used by Josey et al. (1999) among others, would give values for $Q_{\mathrm{b}}$ of 42 , 19 , and $8 \mathrm{~W} \mathrm{~m}^{-2}$ for May, June, and July, respectively. These results would produce a mean of $23 \mathrm{~W} \mathrm{~m}^{-2}$, rather than $9 \mathrm{~W} \mathrm{~m}^{-2}$ (Table 1). On the other hand, the Berliand and Berliand formula, with the cloud factor $1-0.9 C$, as used by Weare et al. (1981) for stratocumulus clouds, gives values of 22, 7, and $2 \mathrm{~W} \mathrm{~m}^{-2}$ for May, June, and July. The mean is $10 \mathrm{~W} \mathrm{~m}^{-2}$ versus our value of $9 \mathrm{~W} \mathrm{~m}^{-2}$ (Table 1). Suggestions of a nonlinear cloud factor appear to result from measurements over land (Budyko, 1974) but are not supported by some measurements at sea (Reed, 1976; Simpson and Paulson, 1979). As discussed above, we believe the method used here is more appropriate for conditions in the Bering Sea.

\subsection{Changes in heat content and heat balance}

Table 1 also lists the computed changes in heat content, derived by Eq. (6). For May, $Q_{\mathrm{t}}$ was $9 \mathrm{~W} \mathrm{~m}^{-2}$ greater than $\partial H / \partial t$; in June, $Q_{\mathrm{t}}$ was $19 \mathrm{~W} \mathrm{~m}^{-2}$ less than $\partial H / \partial t$; and in July, $Q_{\mathrm{t}}$ was $1 \mathrm{~W} \mathrm{~m}^{-2}$ more than $\partial H / \partial t$. For the mean, $Q_{\mathrm{t}}$ 
was $2 \%$ less than $\partial H / \partial t$. This difference actually indicates good agreement considering that three of the fluxes were computed with empirical formulas. It should be noted that there were no temperature measurements in the deepest $10 \mathrm{~m}$ of the water column. If one extrapolates the curves in Fig. 3 to $70 \mathrm{~m}$, mean $\partial H / \partial t$ becomes $153 \mathrm{~W} \mathrm{~m}^{-2}$, and mean $Q_{\mathrm{t}}$ is $7 \%$ less than this value.

\section{Conclusions}

The combination of measured and derived surface heat fluxes and measured changes in heat content of the upper $60 \mathrm{~m}$ only differed by $2 \%$, or $7 \%$ if one extrapolates the temperature curves $10 \mathrm{~m}$ to the ocean bottom. Reed (1978) found agreement within 5\% during June-August 1976. It should be stressed, however, that the fluxes obtained here are more reliable than those derived in Reed (1978), which relied on scattered ships' weather reports and satellite images. Consequently, the relative importance of various processes determined here is more reliable than previously inferred.

Although currents were measured at the mooring, we lack information on horizontal thermal gradients in order to evaluate heat advection or diffusion. The currents themselves were only $1-2 \mathrm{~cm} \mathrm{~s}^{-1}$ toward the northeast, however. Based on results in Table 1, we infer that mean heat advection/diffusion was not greater than $\sim 5 \mathrm{~W} \mathrm{~m}^{-2}$.

\section{Acknowledgements}

We thank D. Kachel for preparing data products. W. Parker, C. DeWitt, and S. Salo helped deploy the mooring and prepared the instruments. N. Bond and C. Ladd provided valuable information and helpful discussion. We also thank the officers and crew of the NOAA ship Miller Freeman. Comments from two reviewers and T. Royer are appreciated. This is contribution FOCI-B392 to the Fisheries Oceanography Coordinated Investigations and is part of the Coastal Ocean Program of NOAA. Contribution No. 2224 from NOAA/PMEL.

\section{References}

Bond, N.A., Adams, J.M., 2002. Atmospheric forcing of the southeast Bering Sea shelf during 1995-99 in the context of a 40-year historical record. Deep-Sea Research II, this issue (PII: S0967-0645(02)00323-5).

Budyko, M.I., 1974. Climate and Life. Academic Press, New York, 508pp.

Coachman, L.K., 1986. Circulation, water masses, and fluxes over the southeastern Bering Sea shelf. Continental Shelf Research 5, 23-108.

Friehe, C.A., Schmitt, K.F., 1976. Parameterization of air-sea interface fluxes of sensible heat and moisture by the bulk aerodynamic formulas. Journal of Physical Oceanography 6, 801-809.

Hermann, A.J., Stabeno, P.J., Haidvogel, D.B., Musgrave, D.L., 2002. A regional tidal/subtidal circulation model of the southeastern Bering Sea: development, sensitivity analyses and hindcasting. Deep-Sea Research II, this issue (PII: S0967-0645(02)00328-4).

Josey, S.A., Kent, E.L., Taylor, P.K., 1999. New insights into the ocean heat budget closure problem from analysis of the SOC air-sea flux climatology. Journal of Climate 12, 2856-2880.

Kalnay, E., et al., 1996. The NCEP/NCAR 40-year reanalysis project. Bulletin of the American Meteorological Society 77, $437-471$.

Kinder, T.H., Schumacher, J.D., 1981. Hydrographic structure over the continental shelf of the southeastern Bering Sea. In: Hood, D.W., Calder, J.A. (Eds.), The Eastern Bering Sea Shelf, Oceanography and Resources, Vol. 1. University of Washington, pp. 31-52.

Moisan, J.R., Niiler, P.P., 1998. The seasonal heat budget of the North Pacific: net heat flux and heat storage rates (19501990). Journal of Physical Oceanography 28, 401-431.

Payne, R.E., 1972. Albedo of the sea surface. Journal of the Atmospheric Sciences 29, 959-970.

Reed, R.K., 1976. On estimation of net long-wave radiation from the oceans. Journal of Geophysical Research 81, 5793-5794.

Reed, R.K., 1977. On estimating insolation over the ocean. Journal of Physical Oceanography 7, 482-485.

Reed, R.K., 1978. The heat budget of a region in the eastern Bering Sea, summer 1976. Journal of Geophysical Research 83, 3635-3645.

Reed, R.K., Stabeno, P.J., 1996. On the climatological mean circulation over the eastern Bering Sea shelf. Continental Shelf Research 16, 1297-1305.

Schumacher, J.D., Kinder, T.H., 1983. Low-frequency current regimes over the Bering Sea shelf. Journal of Physical Oceanography 13, 607-623.

Seckel, G.R., Beaudry, F.H., 1973. The radiation from sun and sky (abstract). Eos, Transactions of the American Geophysical Union 54, 1114.

Simpson, J.J., Paulson, C.A., 1979. Midocean observations of atmospheric radiation. Quarterly Journal of the Royal Meteorological Society 105, 487-502. 
Smith, S.D., 1988. Coefficients for the sea surface wind stress, heat flux and wind profiles as a function of wind speed and temperature. Journal of Geophysical Research 93, 15467-15474.

Stabeno, P.J., Schumacher, J.D., Davis, R.F., Napp, J.M., 1998. Under-ice observations of water column temperature, salinity and spring phytoplankton dynamics: eastern Bering Sea shelf. Journal of Marine Research 56, 239-255.
Stabeno, P.J., Bond, N.A., Kachel, N.B., Salo, S.A., Schumacher, J.D., 2001. On the temporal variability of the physical environment over the southeastern Bering Sea. Fisheries Oceanography 10, 81-98.

Weare, B.C., Strub, P.T., Samuel, M.D., 1981. Annual mean surface heat fluxes in the tropical Pacific Ocean. Journal of Physical Oceanography 11, 705-717. 